\title{
Other Lives of the Image
}

\author{
PATRICIA HAYES AND IONA GILBURT \\ Centre for Humanities Research, University of the Western Cape \\ https://orcid.org/0000-0002-8937-4273 \\ https://orcid.org/0000-0002-6141-451X
}

\section{Retakes in Liquid Time*}

In the wake of intensifying debates on decolonisation and restitution in Africa and its francophone diaspora, a Facebook posting of 6 February 2020 gave an other life to a photographic portrait of the French-Italian explorer Savorgnan de Brazza taken in $1882 .^{1}$ The uploaded digital scan of a photograph from nearly 140 years ago flashed up in a moment of contemporary hypervisibility, offering a visual pretext to denounce de Brazza and the effect of his interventions in Africa virtually and openly on a public post, pulling the image out of the academic and archival environments it had until then mostly inhabited.

Trained at the French naval academy, de Brazza undertook three expeditions to West and Central Africa between 1878 and 1885 under the banner of anti-slavery and supported by the Société de Géographie de Paris and powerful political patrons. Effectively his expeditions helped to establish French territorial claims along the Ogooué and Congo rivers, and the French colony of Congo-Brazzaville was named after him. After his second expedition in the Congo which checked King Leopold's ambitions in the region, de Brazza's public reputation soared. A number of portraits were taken of the explorer at the renowned Nadar studio in Paris, where de Brazza appears against a painted backdrop of the seaside. ${ }^{2}$ Prints of these were placed in albums and can now be seen as single digitised images in the online portal of the Bibliothèque Nationale de France.

* This Special Issue on 'Other Lives of the Image' arises from an international workshop held at the Centre for Humanities Research at UWC, 3-4 October 2019. The co-editors thank all participants and additional contributors to this issue, as well as their reviewers. We acknowledge the generous funding support of the DST/NRF SARChI Chair in Visual History and Theory (Unique Grant 98911). This Introduction takes up a number of issues from the workshop but also addresses longer-standing debates within the Visual History research platform at UWC, including the frequent omission of issues of race and African presences within the global debates on photography. The discussion of Nadar's portrait of de Brazza in this Introduction was therefore not part of the workshop and Special Issue brief, but a means of entry into these more encompassing questions. The authors thank Tristan Guilloux and Manuel Charpy for their kind input on de Brazza's portrait, and the Bibliothèque Nationale de France (BNF) for its reproduction here.

1 Link posted on 6 February 2020, uploaded by the online journal African Heroes on its Facebook page at https://www.facebook. com/africanheroesmagazine/photos/le-violeur-p\%C3\%A9dophile-pierre-savorgnan-de-brazza-officier-de-la-marine-fran\%C 3\%A7aise-/1315719891946791. On the 2006 reburial of the remains of de Brazza and his family in a purpose-built mausoleum in Brazzaville as a negotiation between France and the Congo Republic (as well as Gabon and the Central African Republic), see F. Bernault, 'Colonial Bones: The 2006 Burial of Savorgnan de Brazza in the Congo', African Affairs, 109, 436, 2010, 367-90.

2 Amongst many other activities, Félix Tournachon or Nadar produced an array of portraits known as the 'Panthéon' of prominent public figures and intellectuals in his studio in the 1860s. The date of de Brazza's portraits suggests his son Paul Nadar produced these particular photographs. De Brazza's image went on to appear on cigarette packets, soap wrapping and other consumer items. See Bernault, 'Colonial Bones', 376 fn 24. 


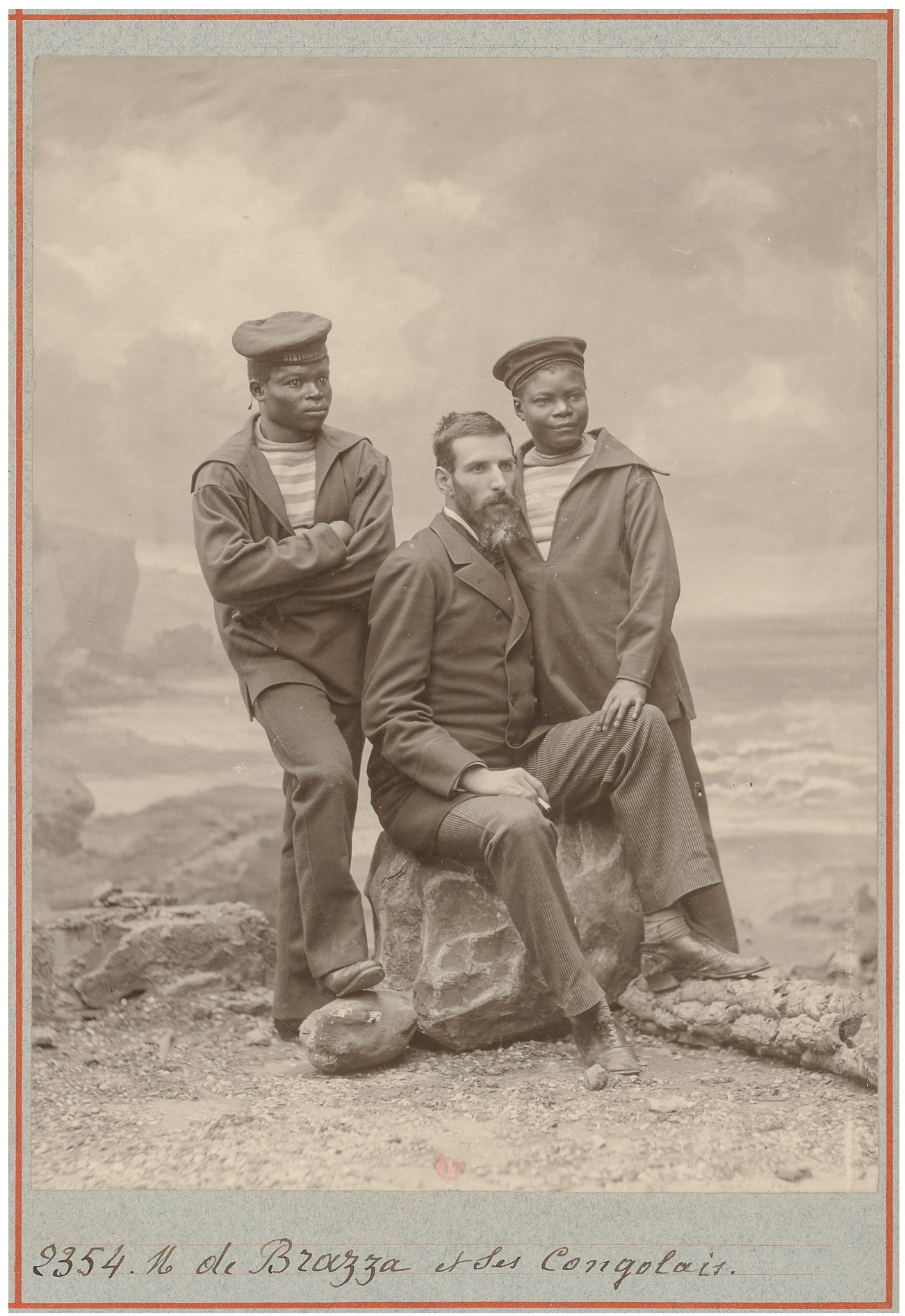

Figure 1: Savorgnan de Brazza et des Congolais. Studio Nadar. Courtesy of the Bibliothèque Nationale de France. 
A number of portraits frame de Brazza alone, including a few where he is dressed in an unspecified indigenous outfit. ${ }^{3}$ Our interest is drawn specifically to two photographs that have the explorer in a plain suit, seated on an artificial rock, with two African youths dressed in naval cadet uniforms on either side of him. ${ }^{4}$ The positioning of their bodies is slightly different in the two images. In both, the handwritten caption on the mounting of the original prints refers to the two youths as 'des Congolais'. One of these is the photograph that made its way to Facebook in February 2020. But it is also immediately recognisable as the very same photograph that Roland Barthes published in 1980 with the caption 'Nadar: Savorgnan de Brazza. 1882'.5 This was in Camera Lucida, one of the most popular and generative texts in cultural and visual studies.

Camera Lucida and its intimate set of meditations is most frequently cited for the distinction Barthes draws between the more predictable informational versus the unpredictable affective aspects of looking at photographs, conceptualised as studium and punctum respectively. It is around the latter that the writing becomes deeply personal. Written in the wake of his mother's demise and (portentously for readers) a few months before his own accidental death, he is driven by concerns of death and mortality. The subsequent allure of Barthes's writing here is in part responsible for why the photograph is so often associated with death in academic discourse. For Barthes, the text is a grasping after intimacy and connection, a break away from the field of semiotics with which he is most associated. Along with other photographs in the essay, 'Nadar: Savorgnan de Brazza. 1882' is filtered through this analytical framework and Barthes's own poetics and 'discretion.'

The terms 'studium' and 'punctum' have, however, come under increasingly direct critical scrutiny for what they tend to obscure. Shawn Michelle Smith, for example, argues, 'Barthes's attempts to define the punctum consistently register a sensation of racial or sexual inquietude.' Smith hones in on problematic, mistaken, or overlooked details in Barthes's discussion of James VanDerZee's 1926 African American group portrait. In this case, Barthes finds the punctum (for him) is the personal memory of his own dead aunt who is not present in the image. This punctum is triggered by (and subsequently supplants) a detail that he in fact misidentifies in the VanDerZee image. In sidestepping the 'uncanny presence of its subject', writes Smith, 'The punctum evades the photograph itself.' ${ }^{8}$ Even more forcefully, Fred Moten points to Barthes's 'reified ontological concern with studium and punctum'. There is a certain solipsism

3 Bernault describes these individual portraits in such dress as 'a feat of Orientalist and bourgeois subjectivity'. Bernault, 'Colonial Bones', 376. The 20-metre-high marble statue of de Brazza erected in 2006 outside his mausoleum in Brazzaville is based on one of these photographs. Along with Théophile Gautier and Pierre Loti, de Brazza is cited as being 'photographed in all manner of costumes' as a way of standing out in what had become quite generic modes of being photographed in the studio. J. Sagne, 'All Kinds of Portraits: The Photographer's Studio', in M. Frizot (ed), A New History of Photography (Cologne: Könemann, 1998), 112.

4 The digital reproduction is located at https://gallica.bnf.fr/ark:/12148/btvlb53120402h?rk=21459;2.

R. Barthes, Camera Lucida: Reflections on Photography (New York: Hill \& Wang, 1981), 52.

6 On Barthes's 'discretion', see J.-M. Rabaté, 'Introduction', in J.-M. Rabaté (ed), Writing the Image after Roland Barthes (Philadelphia: University of Pennsylvania Press, 1997), 8.

S.M. Smith, At the Edge of Sight: Photographs and the Unseen (Durham, NC: Duke University Press, 2013), 23.

Ibid., 27. 
at work, and a problem where 'historical particularity becomes... egocentric particularity. ${ }^{3}$

In this Special Issue we move away from the confines of a narrowly personalised regard to open up Georges Didi-Huberman's broader proposition concerning the afterlife of the image, where he probes what survives in the image, often in spite of all. And partly to belie any semantic slide into associations of death suggested by the term 'afterlife', we move further to propose our own formulation here, that of 'other lives' of the image. ${ }^{10}$ That is the suggestion in our opening sentence with regard to Nadar's portrait and its other life when posted on Facebook. This is different from its other life in Barthes's text, and the author of the Facebook post makes absolutely no reference to Camera Lucida, which forms no part of the post's genealogy. Of course, for us and possibly other readers of Barthes, it manifests the very theoretical text that set us on this path. The other lives of this image then are plural, distinct, discrete, and happening in 'liquid time', a point we take up below. They also have different durabilities: the Facebook image and its polemic are quickly superseded by new ones, while Camera Lucida perdures in a long lineage of scholarly debate. Placing these two lives together here points to some of the tensions and collisions that can happen around photographic images.

In Barthes's discussion of de Brazza, he writes that the punctum that should wound him is the hand of one of the boys that rests on de Brazza's thigh (an 'incongruous gesture'), but it does not. Instead, it is the 'wacky posture' of the other youth with his arms crossed. He concludes: 'What I am able to name does not really pierce me. The impotence to name is a good symptom of trouble. ${ }^{.11}$ While this troubling of the punctum is productive for Barthes and many others, it takes us back to Smith's point that dwelling on the punctum in such photographs means skipping over the studium. Barthes's reference to one youth's 'wacky posture' is a distraction that takes attention away from the racially coded aspects of a set of relationships negotiated in the studio. It results in a skipping over Africa. More generally in Camera Lucida, Moten argues, there is an 'invocation of a silenced difference, a silent black materiality. ${ }^{12}$ This results in an exclusion of what he calls the 'sound/shout of the photograph. ${ }^{13}$ Barthes's reading, then, has seemingly run aground on the shoals of contemporary black thought and its 'remaking of "the human" under ongoing relations of conquest.. ${ }^{14}$

By contrast, the presence of the Congolese youths with de Brazza leads the author on the African Heroes Facebook page to denounce the explorer. De Brazza is castigated, first as a 'paedophile rapist', and then as 'an officer of the French navy who opened the way to the colonisation, and who gave his name to Congo-Brazzaville. ${ }^{15}$

9 F. Moten, In the Break: The Aesthetics of the Black Radical Tradition (Minneapolis: University of Minnesota Press, 2003), 208 .

10 We are grateful to Rui Assubuji for originally making this point.

11 Barthes, Camera Lucida, 51.

12 Moten, In the Break, 205, emphasis in the original.

13 Ibid.

14 T.L. King, The Black Shoals: Offshore Formations of Black and Native Studies (Durham, NC: Duke University Press, 2019), 10 .

15 This site is devoted to the recuperation of little-known or demonised figures from African history, often represented negatively in colonial archives. The corollary is to denounce colonial abuse and misrepresentation. 
What arouses this author is not any 'impotence to name'. Unlike Barthes, he forcefully articulates a sexual and colonial-racial inquietude. This is not the first time de Brazza has been accused of rape, ${ }^{16}$ and as Florence Bernault concludes, 'In Congo and Gabon, the betrayal of trust and alliance, symbolized by rape and incest, is a central trope in the popular remembering of colonialism. ${ }^{17}$ Moreover, the French imperial government had the power to name their colony after him, and this name remains unchanged. On top of this, there has been the return of de Brazza's remains that were ceremoniously re-interred in Brazzaville in 2006 in a political negotiation that brought the return of President Nguesso and the enlargement of French ambitions in a 'suave reconquest' of Central Africa. ${ }^{18}$ In front of the explorer's new mausoleum is an outsized marble statue of de Brazza, modelled on one of the Nadar studio portraits from 1882. The entire episode has been described as 'an improbable parade of neocolonial allegiance. ${ }^{19}$

The encounters with de Brazza's portraits that we have outlined here evoke some of the ramifications of Didi-Huberman's notion of 'survival'. Such survival 'entails a complex set of operations in which forgetting, the transformation of sense, involuntary memory, and unexpected rediscovery work in unison. ${ }^{20}$ These operations obviously become even more dense with possibility if we acknowledge the implications of the turn to digitisation. The agents or actants now go beyond author, spectator and photograph of the analogue era to encompass attributes and databases in the evolving digital realm, as well as the latter's relational algorithms. ${ }^{21}$ When posted online, images also enter into a new sphere of contestation and debate that is made visible in the comments section. Unlike in a published text, this discussion is continually changing as people add, edit, and delete comments. ${ }^{22}$

In their 2013 'digital biography' of Nadar's portrait of de Brazza 'et des Congolais', Boullier and Crépel point out that in the analogue world, the question usually posed is: what captures the viewer's attention and makes the photo circulate? In the digital world, the force of these points of view (they argue) undergoes a complete reprise or retake where the photo and its digital attributes present a 'multiplicity of futures, connection tracks and circulations.'23 We would stress, however, that the 'multiplicity of futures' already exists in the analogue domain: the digital reprise adds to these potentialities and heightens the author's chance of losing control, of disappearing into anonymity behind the object of the image.

\footnotetext{
T. Obenga, 'De Brazza, Faux "Humaniste”, cited in Bernault, 'Colonial Bones', 389.

Bernault, 'Colonial Bones', 389.

Ibid.

Ibid., 368-9.

20 G. Didi-Huberman, 'Artistic Survival: Panofsky vs. Warburg and the Exorcism of Impure Time', Common Knowledge, 9, 2 , Spring 2003, 275.

21 D. Boullier and M. Crépel, 'Biographie d'une photo numérique et pouvoir des tags: classer, circuler', Revue d'Anthropologie des Connaissances, Société d'Anthropologie des Connaissances 7, 4, 2013, 785-813, 790.

22 For example, the views of de Brazza expressed on Facebook did not go uncontested in the comments on the African Heroes site.

23 Boullier and Crépel, 'Biographie d'une photo numérique', 786 (our translation). The authors take up Barthes's discussion of studium and punctum in relation to this portrait of de Brazza 'et des Congolais'. They point out that digital tagging tends to work with the studium, in this case 'de Brazza', which suggests that the punctum identified by Barthes as the 'crossed arms' will never register, and thus the two cadets, 'des Congolais', will tend to disappear from digital searches. The postings on Facebook and elsewhere, however, suggest that other factors are at play and this may not be the case.
} 
All this accentuates a point already made long ago in relation to analogue images - that the temporalities at play are not linear. For Didi-Huberman, 'The time of the image is not the time of history in general. ${ }^{24}$ From the point of view of historicism, the time of the image is 'impure' time, and the way a motif or image resurfaces implies a 'play of "pauses" and "crises," of "leaps" and "periodic reversions". ${ }^{25}$ Nietzsche referred to such returns as the 'inactual' (out of date) and the 'untimely. ${ }^{26}$ This is suggestive in turn of what Marianne Hirsch and Leo Spitzer have conceptualised as 'liquid time', already mentioned above:

We might say that photographs keep developing in unforeseen directions when they are viewed and reviewed by different people in different presents. In 'liquid time' they are not fixed into static permanence; rather, they remain dynamic, unfixed, as they acquire new meanings, in new circumstances. ${ }^{27}$

Hirsch and Spitzer conclude that 'Such a "liquid" and multitemporal reading displaces the retrospective gaze, shadowed by a known and predetermined outcome, that has dominated critical approaches to images of past violence, war, and genocide. ${ }^{28}$

Speaking of predetermination, who in fact are these two youths posing with de Brazza? They are referred to as 'des Congolais' but the studio was in Paris. If they are Congolese, what are they doing there? Are they instead not part of a late nineteenth-century diasporic presence in the French capital? Are their outfits a genuine testament to belonging to a French institution, or do they come from some costume hire or theatre rental? ${ }^{29}$ Perhaps the presence of these black youths was to suggest de Brazza's connection with the African continent. Perhaps the hand on de Brazza's thigh was a pose 'under instruction', to simulate a gesture of trust in the humanitarian man, the 'gentle explorer' and growing celebrity who opposed the slave trade. ${ }^{30}$

These unnamed youths with de Brazza suggest a certain paternalism, positing an infantilisation of colonial subjects and black men that warrants a return to the photograph. As Smith suggests, such a return has the capacity to 'expose the unfinished work of racial justice. ${ }^{31}$ The operative term here is 'unfinished work':

24 G. Didi-Huberman, 'The Surviving Image: Aby Warburg and Tylorian Anthropology', Oxford Art Journal, $25,1,2002,61$.

25 Didi-Huberman, 'Artistic Survival', 275.

26 Cited in G. Didi-Huberman, L'Image Survivante (Paris: Les Éditions de Minuit, 2002), 33.

27 M. Hirsch and L. Spitzer, School Photos in Liquid Time (Seattle: University of Washington Press, 2020), 13.

28 Ibid. See also the review of the book in this Special Issue.

29 Sagne suggests that despite its proliferation, the impression that photographic portraiture had become democratised in France was an illusion. 'In fact, only rarely does one find pictures of peasants, workers or craftsmen in this small format [cartes de visites]. And they generally turn out to be actors photographed in costume - chambermaids, water carriers, and so on.' This is suggestive in terms of de Brazza 'et des Congolais'. Sagne, 'All Kinds of Portraits', 117.

30 The term 'portrait under instruction' signifies a direction to photograph in a particular pose and dress, and comes from J. Ractliffe, Borderland (Barcelona: Editorial RM, 2015). See Aftertext, File 4 Extract 2. The term 'gentle explorer' is cited in Bernault, 'Colonial Bones'.

31 S.M. Smith, Photographic Returns: Racial Justice and the Time of Photography (Durham, NC: Duke University Press, 2019), 1. As the BNF online site makes apparent, photographs from de Brazza's expeditions in West Africa that include important groups of people he encountered at times have their names inscribed on the images, a practice not followed in the Nadar studio portraits. By this time the studio was largely run by Paul Nadar who had taken over from his father Gaspard Félix Tournachon (known as Nadar) after the Franco-Prussian War of 1870-1. Sagne, 'All Kinds of Portraits', 118. For an overview of the elder Nadar's wide-ranging ideas and experiments, see S. Bann, “'When I Was a Photographer": Nadar and History', History and Theory, 48, 4, December 2009, 95-111. 
for this will not be the last reappearance of this photograph. Moreover, while there are 'tensions within and among the methodological approaches to the analysis of photographs', as Jennifer Tucker argues, there remains the potential of photography as a medium to lay bare 'the very processes through which we ... construct the historical record' at different junctures..$^{32}$ Part of these processes must be to acknowledge the 'unknowability' that surrounds the two youths. Such unknowability in fact features in a number of articles in this Special Issue. For the two 'Congolese' here, the lacunae posed by their uncertain identities makes them slip between the possibilities of being African or diasporic European subjects. Amidst the illusions created by the studio backdrop of the liminal beach, we remain at sea.

Yet we continue to pursue this photograph, compelled perhaps by its photographic abundance - a concept that surfaces at important moments in this Special Issue. Elizabeth Edwards has analysed the way a discipline like anthropology sought to obtain 'evidence' from photographs, only to find that what was conceived as evidence tended to become 'conduits of affect'. Such arguments were indeed 'premised on a notion of flawed evidence within problematic regimes of truth', but what this problem has done is to open the 'possibility that affect was evidence, and that embodiment, emotion, materiality were culturally dynamic modes of being in the world. ${ }^{33}$ Edwards insists that photographs suggest these things through what she terms their 'abundance':

The abundance of photographs, both in inscription and the social act of making, opened the possibility of affect and, above all, the recuperation of alternative historical narratives and voices embedded within that abundance. $^{34}$

In looking at de Brazza's portrait now, we are not in some progressive time that brought us here in an enlightened and inevitable way. Something has survived in this image that we read now as a result of many and varied battles, 'latencies and crises', and while it is still a 'transfer of presence' it takes on new historical lineaments and import. ${ }^{35}$ To borrow from the poetic lines of Abdulrazak Gurnah cited by Pamila Gupta in this issue, Barthes's reading has been 'displaced by the friction of other events. ${ }^{36}$ Some of these other events include the anti-colonial struggle, conflicts over racial injustice in the USA and the renewed restitution debates in postcolonial Africa and its former imperial metropoles.

To get at these frictions and the new lineaments taken on by images, we encouraged authors to consider the 'other lives' of the images they work with through some basic initial questions. Why are certain images produced, what in fact happens as

\footnotetext{
32 J. Tucker, 'Entwined Practices: Engagements with Photography in Historical Inquiry', History and Theory, 48, 4, December $2009,4$.

33 E. Edwards, 'Anthropology and Photography: A Long History of Knowledge and Affect', Photographies, 8, 3, $2015,240$.

34 Ibid.

35 The notion of presence is drawn from E. Runia, 'Presence', History and Theory, 45, 1, 2006, 1-29.

36 A. Gurnah, By the Sea (London: Bloomsbury, 2001), 142.
} 
they are produced, and what bearing might these questions have on their subsequent movement or stasis? We also asked what bearing their subsequent movement or stasis might have on the prior and tricky questions of why and how the images were made, unseating earlier assumptions and exposing new instabilities in the image. As Faye Ginsburg argues, the 'impossibility of tethering such media permanently to their originary frameworks - perhaps the foundational premise for what constitutes the risk of visibility - is part of the unruly productivity of these works, as future generations refuse to let unacceptable narratives shape their interpretation. ${ }^{37}$ But what has emerged from the contributions here are not simply a range of interpretive shifts but, more strikingly, a very heightened emphasis on unknowability, obscurity, darkness and opacity. These often come with certain ethical dimensions. This implies large zones of inoperativity subsisting within the more obvious questions about photographic production and movement that warrant a certain reorientation in our thinking, especially about African archives. ${ }^{38}$

\section{Futures, Latencies, Refusals}

To think about the 'other lives' of images often generates a heightened sense of lost futures and of new futures yet to be imagined. This applies most obviously perhaps to photographs that have been locked into certain kinds of framings or formats that have effectively narrowed their meanings. Such constraints might be the result of genre conventions, disciplinary inhibitions, institutional practices or even technological changes. This Special Issue considers newly activated images that had been previously settled, stalled or contained in certain formats, sometimes difficult to access. Many analogue archives in African countries, for example, find themselves in this position. But some have been subject to additional constraints in terms of their political or ritual sensitivity in specific settings of contest and instability. Modes of latency and refusal may operate here, 'retentivities' alongside 'recursivities. ${ }^{39}$

A collaborative project in Uganda has recently begun the enormous work of activating a previously unseen photographic archive housed at the Uganda Broadcasting Corporation. Created during the presidency of Idi Amin, who took an active interest in the photographic shaping of his vision of Uganda, it speaks to Amin's projection of the changes he envisaged for his country and some of the lessons these embodied for its citizens. In this iteration of the research, Richard Vokes traces the genesis of this archive and its practices in the colonial era, when a Photographic Section was driven by post-war developmental agendas and imbued its personnel with a highly competent modernist eye and excellent record-keeping practices. The same documentary practices were grafted onto Amin's project, favouring the still camera. Vokes examines

37 F. Ginsburg, 'Disability, Film, and the Jewish Question', in M. Hjort (ed), Film and Risk (Detroit: Wayne State University Press, 2012), 133-4, emphasis in original.

38 On inoperativity, we benefited greatly from John Paul Ricco's presentation on 'Jean-Luc Nancy: Drawing the Edge of the Commons' at the Zoom Workshop on 'The Politics and Aesthetics of the Common' hosted by Sara Saljoughi of the University of Toronto, 9-10 November 2020. See also G. Didi-Huberman, “"The Potential Not To": Or the Politics of Inoperativity', in R. Görling, B. Gronau and L. Schwarte (eds), Aesthetics of Standstill (Berlin: Sternberg Press, 2019).

Didi-Huberman, L'Image Survivante, 28 (translation Patricia Hayes). 
the circuits of images from this period of Uganda's history that can be traced back to the Photographic Section, as well as of the images taken by non-Section commercial photographers or foreign photojournalists. This meticulous tracking of what gets sent out and why, and how these and other photographs spread through East African and London agency networks, points to a number of anomalies and limits in what might be expected of a state-sponsored Photographic Section. The majority of Section photographs were withdrawn from possible circulation. At a certain point it was decided that photographs would be taken but not printed, just stored as negatives. This collection therefore continued a strange 'other life' under lock and key, a shrouded archive hidden away for decades.

Part of this sequestration has to do with the relationship between photography and state violence in Uganda, and the Section archive does contain exemplars of public executions. Moreover, as Vokes's research reveals, the Entebbe episode demonstrated how taking photographs could be fatal. During the Ugandan-Tanzanian war of 1979 it was simply considered 'suicide.' The result is that what has been made visible through photographic production and circulation via the international taking up of certain kinds of photographs is highly selective and indeed skewed and out of scale. The portrayal of group and even mass killings during Amin's rule has a disproportionate prevalence through the workings of what Vokes calls the 'labyrinthine character of the contemporary global image world', when the vast number of individual killings in that period happened under highly concealed conditions. In fact, it is what the Photographic Section (belatedly) does and does not show that points to a certain unknowability, leading Vokes to conclude that the period of the 1970s in Uganda 'burns with a strange penumbra'.

A sense of things being withheld also features in Christopher Morton's article that addresses the question of 'limits' in relation to a selection of field photographs from Kenya and the Sudan by the British anthropologist Evans-Pritchard in the 1930s. Morton argues that it is obscurity - 'what is not readily or only partially visible, describable, comprehendible and hence legible and understandable' - that should be acknowledged as an important feature of the visual abundance of the photograph. He makes the intriguing point that these 'process their way across the archive'.

Morton alights on two forms of photographic obscurity that mark EvansPritchard's ethnographic fieldwork with the camera: distance and darkness. The former is where the notion of the 'attempted portrait' comes in - botched, and thereby more interesting because suggestive of the movement of social phenomena through representation from one cultural setting to another. It imparts the 'fugitive nature of anthropology's subject' that avoids frontality or moves out of range of the capacity of the lens to magnify its object. In the col wic ceremony that is performed in the liminal moments between night and day, making a 'harmony of darkness' with the black hide of the cow, it is the very limitations of the camera that fail the anthropologist. Morton points out the overlooked issue that anthropological photography had of necessity to be 'a daytime affair'. The existence of these photographs in the archive point to such limits as an underexplored and important aspect of 'abundance'. 
John Peffer goes even further in his contribution to urge the development of new approaches that directly 'allow for and engage with people's desires for obscurity'. He asks us to consider an 'ethics of looking' and a need for opacity that can supersede the desire of researchers, curators, and art dealers, among others, to repackage and redisplay African photographs. These questions arise for Peffer from his research on family collections of photographs in predominantly black South African urban areas. The author starts from an existing binary that posits portrait photographs as a space of 'dignity' and family centrality amid social crises under apartheid as a counter and 'antidote' to those gritty documentary images of violence and unrest seen outside the country. ${ }^{40}$ These latter are said to be 'overdetermined images of Black bodies-asspectacle, whereas portrait photographs can be viewed as quieter acts of self-determination within the privacy of the family. Where Peffer's work breaks completely new ground, however, is to assert that this very privacy is threatened if we succumb to the valorisation of the image and its role in the photographic history of South Africa. We should first be asking whether and, if so, how these photographs should be reproduced, discussed, and disseminated. Peffer highlights numerous reasons that families would want their photographs kept out of view. The images may invoke the memories of strained family relations, of illegitimacy, of trauma, and of the 'degradation that came from living under a racialised state: broken families, alcoholism, marital violence. In Peffer's work, the designation 'family photography' is reworked to draw in the 'dynamic aspirations and tensions that exist within families as well as the right to choose to not be looked at by the prying eyes of strangers' and thus to make familiar the demand for opacity as a quality inherent to the genre.

Peffer leads us to the important question of how to write ethically about family photographs, making an injunction to move beyond the fascinations with notions of 'spectacle', 'discovery', and 'salvage', and to instead place our responsibility to the subjects we work with at the centre of our discourse. Too often, families have seen the commodification of their private photographs on the African art market. Even in his own research, Peffer has been confronted by the suspicions of those who believe their photographs will be exploited financially if handed over to an outsider. What position should the researcher take when confronted with the family's right, as owner and curator of its own archive, to retreat from view and self-determine the other lives of its photographs? In thinking about such refusals, Peffer chooses to speak to the 'individuality of lives as lived' and 'explore the texture of experience on the micro-historical level, while honouring the dignity subjects claim through their personal creation and collection of images of themselves'. The ethical nature of Peffer's response that allows for an engagement with people's desires for obscurity is encompassed in the researcher's own refusal to inhabit the opacity offered to the writer. Rather than slip into anonymity and use images as he pleases, he narrates encounters in which he is

40 For a discussion of the binaries constructed around African portrait photography, see P. Hayes and G. Minkley, 'Introduction: Africa and the Ambivalence of Seeing', in P. Hayes and G. Minkley (eds), Ambivalent: Photography and Visibility in African History (Athens, OH: Ohio University Press, 2019), 12-14, and G. Minkley, 'The Pass Photograph and the Intimate Photographic Event in South Africa', in Hayes and Minkley (eds), Ambivalent, 107-8. 
compelled to honour the request not to show. He acknowledges that, in looking at family photographs, not all other lives are meant to be lived. Peffer's intervention here takes us to a new level in the longstanding debate around harmfulness and healing in African photography. ${ }^{41}$

At another point in this spectrum, Jordache A. Ellapen enters a treasured collection of photographs of his mother as a young woman in the Natal Midlands, in search of something 'distant' in them that he wishes to reach into and activate in the present. Largely hidden from the family and now curated through Ellapen's own queer sensibility, he foregrounds them as photographs of feminist futurity. They hold a part of his mother that had become distant, even to herself after marriage and motherhood, and they direct the author and son towards the 'dreams and desires' that made it possible for her to stand out differently against the backdrop of the studio. Ellapen insists that these cannot be understood outside the lived experiences of colonial indentureship and its afterlives in South Africa, within those 'racial hierarchies that exacerbated gender inequalities' that could spill into violence within the 'home-space'. He sees his mother's studio photographs as performances which conceal her everyday life and as a refusal, for her, of 'regimes of violence, regulation and death'.

Colonial regulation of indentured Indians migrating to the colony of Natal in the late nineteenth century left its imprint in the ID photographs arranged in a grid that offers a template for Ellapen's reworking of his mother's ID photos into a composite image with a different inflection. These 'other lives' connect the author/artist to earlier generations and indeed the 'invisibilised... afterlife of... indentureship' as South African Indian subjects became increasingly homogenised from the mid-twentieth century. The semi-rural Natal Midlands and its 'multiple contours of Indianness' have had scant historiographical attention in this regard. The 'desire for the otherwise' palpable in the studio images at the centre of Ellapen's 'Brown Photo Album' thus offers a site of reconstitution and reimagination as well as a 'grammar of futurity'.

\section{Other Media, Other Languages}

Ellapen's composite image on our cover is a reminder that in taking on other lives, photographs are very often transferred across media, emerging in literature, cinema, sculpture, visual art and media installations, amongst numerous other manifestations. Artists frequently 'unveil secret conversations between media', and these might carry on 'across decades and geographical realms, revealing difference between old and new without asserting its absoluteness. ${ }^{42}$ Such transpositions often fall under the designation 'intermediality', though both this concept and its associate term 'medium' are problematic ${ }^{43}$ and must be considered against the complex question of

41 See especially H. Behrend, Contesting Visibility: Photographic Practices on the East African Coast (Bielefeld: Transcript Verlag, 2013).

42 K. Beckman and J. Ma, 'Introduction', in K. Beckman and J. Ma (eds), Still Moving: Between Cinema and Photography (Durham, NC: Duke University Press, 2008), 7.

43 W. Wolf, '(Inter)mediality and the Study of Literature', CLCWeb: Comparative Literature and Culture, 13, 3, 2011, doi. org/10.7771/1481-4374.1789. 
medium specificity and the ways in which we attempt to mark out media boundaries. Mary Ann Doane asserts that 'medium specificity is a resolutely historical notion, its definition incessantly mutating in various sociohistorical contexts'. She cites Griffith and Eisenstein who saw in film editing and montage, for example, 'the true potential of the medium', while in the 1970s and 1980s Structural filmmakers centred attention on 'film's material base. ${ }^{44}$ Doane evocatively describes intermediality as 'a drama of identity and its loss and subsequent regeneration' as media converge to 'generate new forms and possibilities that rely on the "haunting" effect of earlier singular media. ${ }^{45}$ We are reminded of the multitemporal reading explored by Hirsch and Spitzer in their theorisation of liquid time ${ }^{46}$ While we may write of photographs as transferred across media, we do so against the awareness of a nonlinear temporality in which the 'media' involved (photography included) are subject to multiple redefinitions in relation to each other and within a sociohistorical context. The intermedial act thereby places attention on how and why images are redeployed and reimagined, unveiling the 'question of the medium to be, among other things, [as] a question of history, temporality, and relationality.47

In this issue, Iona Gilburt considers how photographs take up 'other lives' beyond their visual iterations as they move into prose and critical discourse in phototexts. At times these images remain visible as reprints, yet in other instances they are the unseen allusions of ekphrases - mental impressions formulated in the mind of the reader/viewer. Gilburt discusses how the late nineteenth-century photographs of Jean-Martin Charcot's female patients from the Salpêtrière hospital in Paris, in particular those of teenager Louise Gleizes (known as Augustine), have proliferated into art periodicals, theatre, cinema, and literature. The images of Augustine in the throes of the hysterical attack became a fascination for the surrealists in the 1920s, and they promoted an idea of the hysterical woman as a poetic gesture of freedom. In tracking the emergence and formation of the perception of hysteria, Gilburt considers that such phototexts produce a palimpsestic image. The 'other life' of the medical photographs from the Salpêtrière surfaces in mental formations that overlay the actual prints and are transferred across new generations of texts.

In the journey of these photographs through the surrealists' writing and into later iterations, a stereotypical and gendered image of illness emerges and continues so that whomever enters into a conversation with the photographic history of the Salpêtrière is forced to reproduce hysteria's stereotype. A conscious acknowledgment of one's complicity in this formation opens up a site from which to subvert and critique the feminisation of illness. In working with images of pain and suffering, however, there is the risk that one is merely taking advantage of someone who is already victimised. The extreme manifestation of this failing is pointed out by Linda Steer, who views the reuse of the crime-scene photograph of Jack the Ripper's victim Mary Kelly as 'a new 1, 2007, 129 .

45 Ibid., p. 148, note 2.

46 Hirsch and Spitzer, School Photos in Liquid Time.

47 Beckman and Ma, 'Introduction', 7. 
horror..., re-enacting the evisceration of this woman whose body was always available for exchange. ${ }^{48}$ The Kelly photograph is a blatant example of unethical appropriation and dissemination. Where researchers choose to appropriate and transpose photographs, Peffer's caution about the need for an ethics of looking is salutary. In many situations, misuse is harder to discern and questions of replication are murky.

Yet appropriation can also lead to constructive outcomes. Michael Aird describes an extremely suggestive intervention in the work of artist Vernon Ah Kee, with whom he collaborated on a 2012 exhibition. Ah Kee produces drawings of photographic portraits of his ancestors. He uncovered these photographs of his grandfather and great-grandfather in the State Library of Queensland, Australia ${ }^{49}$ Several were taken in 1938 by archaeologist Norman Tindale, whose work has taken on great authority in native title claims despite inconsistencies and factual errors, as discussed by Aird in this Special Issue. Ah Kee's work exhibits what Ágnes Pethö describes as an erasure of a perceived medium, which is possible in the intermedial act. ${ }^{50}$ Pethö gives an example from Godard's film Le Petit Soldat, in which the description of the sky as looking like a Paul Klee painting both evokes the medium of painting while 'painting as a directly perceivable medium' is erased..$^{51}$ Ah Kee's drawings instigate the disappearance of Barthes's famous referent: the element of the real that is seared into the image. The photographic index contains the transfer of light from real object onto photographic materials. Ah Kee removes the profilmic situation, replacing the hand of the photographer with the hand of the artist, who has the truly personal connection to the figures in the frame. The transposition is an act of reclaiming the photograph and its historical import as, with each stroke, Ah Kee crafts an intimate connection across generations.

\section{Reworkings}

The need to reclaim photographs themselves and put them to new kinds of work is at the heart of Michael Aird's own photographic project. ${ }^{52} \mathrm{He}$ transcends problems of genre and institutional constraint by assembling as many photos as possible that originate as ethnographic, studio, or family photographs, to enable him to recover Aboriginal persons, families, lineages and their lines of movement in Queensland, from the mid-nineteenth century. He is not inhibited by 'objectification' and apparent racism - the 'unthought of colonialism' - and deliberately ignores the problematic cartography that relates particular tribes to fixed, atemporal land areas. In doing so, he has plunged us into a new debate, as things leak out that European studio photographers never previously thought or conceived of in this medium. Photography, 32, 2, 2008, 111, doi: 10.1080/03087290801895647.

49 Some images discussed here are available at: https:/www.mca.com.au/artists-works/works/2006.11.9/ (Museum of Contemporary Art Australia).

50 Á. Pethő, 'Media in the Cinematic Imagination: Ekphrasis and the Poetics of the In-Between in Jean-Luc Godard's Cinema', in L. Elleström (ed), Media Borders, Multimodality and Intermediality (Basingstoke: Palgrave Macmillan, 2010), 211-22.

51 Ibid., 218-9.

52 Michael Aird delivered the keynote lecture at the International Workshop on 'Other Lives of the Image' at the University of the Western Cape in October 2019. 
Aird has developed his own working categories in this process, which focus on 'people as people' and consider, among other questions, their 'being comfortable' and participating in the photographic exchange willingly. Aird was motivated by another kind of intelligibility: thought and sense-making that is ingrained in Aboriginal matters of family and genealogy, as well as the land. This is how, in his treatment of images, people become people, rather than often being the anonymous personages of historical collections. He is thus engaged in taking photographs out of their ossified museum lineages and into another forum, the land grant court that is seething with activity and filtering new 'evidence', though still apparently reluctant to let go of its older categories of 'expertise'.

The construction of a colonial lineage of photographs of conquest and 'effective occupation' in Mozambique after the Berlin Agreements of 1884-5 becomes evident in Rui Assubujis exploration of portraits of the Gaza king Ngungunyane. After Portuguese military forces overwhelmed the last autonomous and centralised African kingdom at Chaimite in 1895, Ngungunyane was posed before the camera at various points on the long journey to exile. Assubujis close study of these portraits traces their multifarious 'other lives' as some images become partitioned and the king's sole figure reappears across a range of formats that includes ceramics. At times slippages emerge in their ongoing repositioning in both analogue and digital domains, with misidentifications of persons and places that point to fascinating levels of genericisation as new productions continue to emerge. This forms part of Assubuji's argument about the 'often unexpected findings of the existence of different moments within a single image, and where 'some things stick and persist, others do not, and the image travels in a new narrative'.

Elsewhere it has been argued that such portraits of defeated African kings in the late nineteenth century are a 'photographic dethroning' where the king or chief moves from the 'sovereign command of an entire nation to provincial isolation elsewhere. ${ }^{53}$ While the precolonial history of such territories remains almost entirely unphotographed, there is a danger that such royal portraits stand in for entire epochs. ${ }^{54}$ Assubuji delves, however, into missionary archives to draw out more spontaneous and inclusive images that put Ngungunyane, his family and subjects on a very different footing. He also draws attention to the acute anomaly that official Portuguese photographs tend to show nothing at all of the actual violence that was unleashed on Gaza. This resonates with Vokes's point regarding the official Photographic Section decades later during the Amin regime in Uganda. Both leave little visual record of their actual violence and a great deal of murk amid the political relations and presentations of power negotiated around these archives. For Assubuji, working with the concept of 'other lives' means that 'the realisation of how one image might be disassembled to generate others becomes an exercise - in visual terms - of rethinking colonial violence.

53 P. Hayes, 'Photographs on the Edge of History: Genre, Time, and Conquest in Southern Africa', in T. Campt, M. Hirsch, G. Hochberg and B. Willis (eds), Imagining Everyday Life: Engagements with Vernacular Photography (Göttingen: Steidl, 2020), 43-5.

Ibid., 45 . 
The workings of power within representation brings us to Christopher J. Lee, who sets to work in using generic and theoretical complications to articulate the complex set of relations depicted in the visual archive of the 1955 Asian-African Conference, held in Bandung, Indonesia. Known more widely as the Bandung Conference, it comprised 29 delegations from countries in Africa and Asia, and became a world stage for leaders such as Jawaharlal Nehru, Zhou Enlai, and Gamal Abdel Nasser, among many others. Most of the nations there had already achieved independence. Key issues on the table included postcolonial sovereignty, economic and trade developments, US and Soviet influence, and concerns related to the expanding decolonisation in Africa. In considering this significant expression of postcolonial diplomacy and Third World internationalism, Lee formulates the concept of the 'decolonising camera' to include both the act of documenting decolonisation and the 'ways in which visual archives produced during decolonisation can contribute to new iconographies of the political, which are both factual and mythic at once'. In working towards an understanding of the 'Bandung Spirit' through an incisive gaze at the postcolonial iconography created in that moment, Lee is drawn to the rather startling street photographs within the archive.

Despite what one might consider a security risk to such high-profile political figures, the delegates walked every day from their hotels to the Freedom Building in which the conference was held. This became known as the Bandung Walk and was recorded in photographs that are a combination of both street photography and photojournalism and, as Lee adds in the further complication of genre, 'a blending of street photography and diplomatic portraiture'. Lee reads these photographs as generating an anti-hierarchical impression of a shared space with the crowds while also promoting a sense of conviviality and postcolonial camaraderie and cooperation. Lee, however, is also careful to place this iconography within the context of what was also a carefully managed event, noting how many leaders used the moment to assert nationhood as 'delegates wore clothing and uniforms that reflected cultural identities and political power. Indeed, despite the Third World solidarity being promoted, nationalism was on full display'. Lee furthermore calls our attention to how the Bandung Spirit crafted in this moment, in this urban space, which would go on to have other lives, was also decidedly one of 'postcolonial masculine camaraderie'.

Candice Steele's article on the Eastern Cape points to the way the urban-rural divide has conventionally fed into a longstanding dualism that positions rural subjects as 'traditional', setting them almost automatically outside modernity. Steele's exploration of parts of Dr Pauline Ingle's collection that suggest an ambulatory, candid and proximate way of photographing what she calls the 'socially performative' activities between hospital, church and everyday rural life, tends to break down such dichotomies. Steele draws on Gary Minkley's concept of the 'social act' that allows for narratives that are non-linear, 'competing, convivial, conforming or non-conforming' at the same time. Most insightfully, she asks how we should understand 'constructions of rural individuality' through the individual portraits taken by Ingle in the Eastern Cape, because these pose a big question about whether such portraits posit a modern sensibility that existing literature tends to see only as urban. 
As with several other articles in this Special Issue, Steele draws out the multiple temporal dimensions latent in images. The most striking of these is the photograph of the woman leaving the hospital with two geese wrapped up on her head, casting a shadow reminiscent of the threshold space employed by shadow theatre to link tradition with the contemporary. For Steele, this points towards a future holding something other than the usual projection of poverty. She likewise dwells on the kinetic aspects of a further image of rural women going home, where the sense of movement suggests futures that are open, indeterminate rather than overdetermined.

Like Steele, Inês Ponte engages with an archive that is ostensibly built around rural subjects but which can take us in many directions. Ponte's engagement here is not only that of a researcher; her questions arise from her position as archivist brought in to evaluate the state of the collection of the late Angolan anthropologist Ruy Duarte de Carvalho, and charged with the responsibility to mobilise and make it accessible for others. ${ }^{55}$ Carvalho was something of a polymath, an agronomist who became a filmmaker and then turned to anthropology along with many other creative and research-based activities. Carvalho initiated fieldwork among ovaKuvale agro-pastoralists in southern Angola after the 1992 national elections to find out what might be learned from such a marginal group in what he hoped was to be the 'aftermath of war. ${ }^{56}$ Over a number of challenging visits to the south he worked with various cameras and modes of documentation that he then repeatedly revisited for different exhibition and performative purposes in Portugal and elsewhere. These reworkings are the focus of Ponte's analysis in this Special Issue.

In trying to assess how, when and why Carvalho reworked his images, Ponte finds a temporal unpredictability and lack of linear logic in the archive that she associates with Didi-Huberman's notion of 'impure time.' Carvalho not only reprocessed certain photographs from ritual and everyday practices amongst ovaKuvale through tone, filters and cropping, he also later produced drawings and watercolours that can be related to particular field photographs that Ponte views as part of dynamic 'labours of maturation'. Drawing and painting by hand not only reconnected Carvalho to his fieldwork experiences, but allowed him to 'think for resonances' and take what Ponte calls 'imaginative leaps.' This capacity and indeed compulsion to keep experimenting with different ways to express his fieldwork experience, often 'grounded in his field photography', suggest a 'gradual and undetermined education of his attention'.

It also recalls something of the 'unfinished work' that is implicit in photographic images that we invoked earlier in relation to Nadar's portrait of de Brazza 'et des Congolais'. It reiterates the point that photographs cannot be fully seen, whether at the time of their making or at any one of their later reappearances. A residual 'unknowability' makes its way across the archive (Morton). They are 'difficult to see' (Vokes). The term Nachträglichkeit (belatedness) comes to mind, suggesting elements

55 The ongoing work on Carvalho's archive and those of other anthropologists in southern Angolan can be visited at http://www. hisfotant.org/.

56 For recent scholarship on Angola, its war/s and aftermaths, see the previous issue of Kronos, 45, 2019, Special Issue on 'Angola: Nationalist Narratives and Alternative Histories'. 
that only become apparent to consciousness at some unpredicted future time ${ }^{57}$ But it is also more than that: potentiality is also the 'power not to. ${ }^{58}$ The motif of inoperativity is increasingly pertinent here, this 'power "by which night opens"." 59

\section{Into the Dark}

As much as photography means 'writing with light', we must acknowledge that this light is formed amid darkness. In her meditative journey through the trope of darkness, Pamila Gupta sees the import of speaking the language of the dark photographically. Entering the Capital Art Studio, the last studio in Stone Town, Zanzibar, opened by Ranchhod Oza and then inherited by his son Rohit Oza, she encounters the making of Zanzibar's island identity and the many iterations of darkness, as metaphorical and manifest, that are imbricated in its history. Ranchhod Oza photographed Zanzibar in its life as a thriving port from the 1930s to the early 1960s and experienced Zanzibar's shift from being a cosmopolitan Indian Ocean port city through its period of revolution and into its becoming a tourist destination. The images that emerged from a darkroom that is no longer there have travelled across time into multiple iterations that are made visible when one attends to the dark. Taking the darkroom as agentive space, Gupta asserts the importance of envisioning it beyond its physical reach. The darkroom was where Zanzibar was 'made representable as an island space through the medium of photography'. The waters within the photographic darkroom can also be taken metonymically for the waters of the island, with its famous dhows, and the paths where spices, ivory, and slaves were transported from Africa to Europe. If the photography studio is an island within an island, the waters within the darkroom are a sea within a sea, a nexus for the intricate relations of darkness.

The darkroom held a key space amid a time that Gupta conceives as a visual darkness, when the Sultanate was deposed in the Revolution of 12 January 1964. It was dark visually as photographic practices were initially restricted under the new Afro-Shirazi party and public photography banned. Photographers then worked under the cover of darkness. In this period, alignments with the symbolism of light and dark clashed. As Gupta asserts, for many this was a time of 'political lightness', when Zanzibar was opened to its mainland and where political power was taken away from an elite few supported by declining British colonial powers. Gupta's work with Ranchhod Oza's archive is itself a way of reframing photographs and moving them into 'the distinct light (and lighting) of the early twenty-first century, and unmooring this island from its Omani Sultanate and British Protectorate hold. Yet for those who did not support the Revolution, it became a time of 'political darkness', of violence and secrecy and chaos. Ranchhod Oza, formerly the official photographer for Omani Sultan Khalifa bin Haroub, had to burn all Sultanate images inside the studio. Capital

57 See Ross Truscott's review of Ambivalent in this Special Issue for a discussion of Freud's use of this concept.

58 G. Agamben, Potentialities: Collected Essays in Philosophy (Stanford: Stanford University Press, 1999), 179-84. See too Ariella Aïsha Azoulay, Potential History, also reviewed in this volume.

59 Didi-Huberman, "“The Potential Not To"”, 204, citing M. Blanchot, The Space of Literature (Lincoln: University of Nebraska Press, 1982), 171. 
Art survived as many other studios were closed. In a further nod to its island identity, the darkroom continued to hold the troubled waters of transition.

The agitations and gestations of the darkroom's processing are apt analogies for Georges Didi-Huberman's Uprisings. As we see in Sam Longford's review article, many of the frictions that pervade this issue come together in this work. Longford points out how Didi-Huberman's writing engages with photography as a medium that can both blur and reveal, that can both overexpose and underexpose, and that is of many temporalities. The bringing together of traditions and histories of uprisings, rebellions, and revolts in Uprisings is as much an account of the past as a gesture towards future uprisings. Longford interprets Didi-Huberman's idea that we are and have always been rising up as an expression of our desire for freedom -... [as] intrinsic to human behaviour. This is the realm where the smallest or greatest act can be of immense significance and where uprisings are of the order of the best and the worst that we have to offer in dark times. Longford thus aptly begins his meditation with the declaration that the text is 'at once heavy and light'. In his call for the new (images, thoughts, possibilities), Didi-Huberman draws together images of gestures that, Longford writes, 'produce a vision of an endless, collective scream', able 'to put the world as we know it into motion'. The author's proposal is to 'read Uprisings as a gesture of radical solidarity for the global South (for us to use) rather than a text about it'.

The final section of this Special Issue looks at three recent texts that offer a range of resources we might need as we continue to set 'other lives' in motion for images. In respect of those that have been neglected, Rory du Plessis commends Marianne Hirsch and Leo Spitzer's School Photos in Liquid Time 'for directing academic attention to a genre of vernacular photography that has received only a paucity of scholarly and historical investigation'. In unearthing the multifaceted narratives of such previously overlooked images, the text brings 'an awareness of the policies of exclusion and integration that were operational at various educational institutions'. Bianca van Laun engages with Ariella Aïsha Azoulay's Potential History as an injunction for 'unlearning' modes of imperial thinking and undoing knowledge structures, as Azoulay constitutes violence in 'its still-present potentialities' as part of the move to think before imperialism. While in agreement with Azoulay's argument, van Laun notes that much important work in this 'unlearning' is already being undertaken in the global South.

Finally, Ross Truscott's review of Ambivalent highlights the conceptual breakthroughs of a new generation of African scholars who address themselves to the global debates on photography. He describes how, in working with the concept of 'ambivalent', the collection becomes a valuable resource in questioning many of the binary divisions and generic assumptions applied in humanities scholarship of Africa more generally. As Truscott observes, the concept of ambivalent 'is a way to ceaselessly question old and new oppositions' that often represent 'a conflicted masking' rooted in social conditions and, we would add, legacies of colonial epistemologies.

Truscott speaks of the 'overdetermined scene of the photographic field' in Africa. In very direct ways, Ambivalent takes up the problem of the 'historical and political 
abysses cast by light' and brings to bear the notion of 'nonlight' that also serves as a 'constitutive practice of power and privation'. ${ }^{60}$ This in turn is suggestive for a Special Issue where the 'other lives of the image' might reside within a spectrum that includes the penumbral, the elusive and the completely obscure.

60 Hayes and Minkley, 'Africa and the Ambivalence of Seeing', 5, citing A. Feldman, Archives of the Insensible (Chicago: Chicago University Press, 2015), 8. 